\title{
Effects of salinity on the physiology of Salvinia auriculata Aubl. (Salviniales, Pteridophyta)
}

\author{
José Bonomi-Barufi ${ }^{1 *}$ \\ Vanessa Freire de Carvalho ${ }^{1}$ \\ Fernando Scherner ${ }^{2}$ \\ Leonardo Rafael Chaves Coelho Xavier ${ }^{2}$ \\ Edson Gomes de Moura-Junior ${ }^{2}$ \\ Manoel Messias da Silva Costa ${ }^{2}$ \\ Bety Shiue de Hsie ${ }^{2}$ \\ Micheline Kézia Cordeiro de Araújo ${ }^{2}$ \\ Maria Claudjane Jerônimo Leite Alves ${ }^{2}$ \\ Gemima Manço de Melo ${ }^{2}$ \\ Natália Maria Corte Real de Castro ${ }^{2}$ \\ Douglas Correia Burgos ${ }^{2}$ \\ André Luís de França Dias ${ }^{2}$ \\ Patrícia Campos de Arruda-Queiroz ${ }^{2}$ \\ Sônia Maria Barreto Pereira ${ }^{2}$ \\ ${ }^{1}$ Universidade Federal de Santa Catarina, Departamento de Botânica \\ Campus de Trindade, s/n, Trindade, CEP 88040-900, Florianópolis - SC, Brazil \\ ${ }^{2}$ Universidade Federal Rural de Pernambuco, Departamento de Biologia - Área de Botânica \\ Programa de Pós-Graduação em Botânica \\ Rua Dom Manoel de Medeiros, s/n, Dois Irmãos, CEP 52171-900, Recife - PE, Brazil \\ * Corresponding author \\ jose.bonomi@gmail.com
}

Submetido em 12/09/2016

Aceito para publicação em 16/05/2017

\section{Resumo}

Efeitos da salinidade na fisiologia de Salvinia auriculata Aubl. (Salviniales, Pteridophyta). A macrófita aquática Salvinia auriculata Aubl. ocorre em diferentes regiões do Rio Capibaribe, no estado de Pernambuco, Brasil. Esse rio desemboca no mar e, consequentemente, apresenta setores com diferentes gradientes de salinidade. Este trabalho avaliou a fotossíntese, o crescimento e o teor de pigmentos fotossintetizantes de $S$. auriculata frente a um gradiente de salinidade. As plantas foram obtidas em um reservatório no município de Paudalho e foram levadas à casa de vegetação, onde foram mantidas em frascos de vidro contendo $250 \mathrm{~mL}$ de volume preenchido, posicionados em bancadas durante 40 h nas seguintes condições de salinidade: 0,17 e 34 , obtidas com água doce, mistura de água doce e salgada e água salgada, respectivamente. Ao final, as folhas 
das plantas tratadas com água salgada apresentaram mudança na coloração (de verde para marrom) e também as plantas tiveram redução no seu crescimento. A salinidade e o tempo afetaram negativamente as respostas fotossintetizantes das plantas, com diminuição de $F_{\mathrm{v}} / F_{\mathrm{m}}, \mathrm{ETR}_{\max }$ e $\alpha_{\mathrm{ETR}}$ conforme aumentava o conteúdo de sais ao qual as plantas estiveram expostas. Os padrões de respostas obtidos ajudaram a esclarecer a distribuição de S. auriculata, podendo ser regulada pela salinidade.

Palavras-chave: Fotossíntese; Fluorescência da clorofila $a$; Macrófitas; Rio Capibaribe

\section{Abstract}

Salvinia auriculata Aubl. is reported to occur in different zones of the Capibaribe River, Pernambuco State, Brazil. This river varies in salinity in different areas. This study evaluated the growth, photosynthesis and pigment contents of S. auriculata at different salinity levels. Plant sections were collected in the Cursaí Reservoir, located in the municipality of Paudalho, Pernambuco, and were brought to a greenhouse, where they were put in glass flasks filled with $250 \mathrm{~mL}$ of liquid, placed on benches. The plants were exposed for $40 \mathrm{~h}$ to salinity levels of 0 , 17 and 34, obtained with reservoir freshwater, 1:1 freshwater:seawater and pure seawater, respectively. At the end of the experimental period, the plants in salt water showed color changes, with brownish leaves. In addition, plant growth rates decreased. Salinity and time had a negative influence on photosynthetic responses such as $F_{\mathrm{v}} / F_{\mathrm{m}}, \mathrm{ETR}_{\max }$ and $\alpha_{\mathrm{ETR}}$, which showed reductions under the highest salinity treatment. Response patterns may help to explain $S$. auriculata occurrence, and its distribution can be regulated by salinity.

Key words: Capibaribe River; Chlorophyll $a$ fluorescence; Macrophytes; Photosynthesis

\section{Introduction}

Macrophyte assemblages are important ecological constituents of aquatic limnetic systems (lotic or lentic ones), where they are the main primary producers in these environments (ESTEVES, 1998). In other ecological roles, macrophytes provide refuge for larval reproduction of other organisms and act as bioremediation agents, absorbing particulates and heavy metals. They participate in nutrient cycling, regulate dissolved oxygen in the water and offer substrate to periphytic communities (ESTEVES; CAMARGO, 1986; ESTEVES, 1998; KLUMPP et al., 2002; RIGOLLET et al., 2004; DINIZ et al., 2005; THOMÉ, 2008; DESMET et al., 2011).

Salvinia spp. are free-floating freshwater macrophytes that show an explosive growth rate under favorable conditions (GARDNER; AL-HAMDANI, 1997), such as nutrient enrichment caused by human activities (BINI et al., 1999) and high concentrations of $\mathrm{NH}_{4}^{+}$and $\mathrm{NO}_{3}^{-}$(JAMPEETONG; BRIX, 2009a). This explosive growth can bring about negative consequences to aquatic ecosystems (ESTEVES, 1998). These plants can have competitive advantages when associated with other species, such as Typha domingensis Pers. (TRINDADE, 2008), facilitating dispersion and dominance in aquatic environments.

There are also positive perspectives for Salvinia spp. Several studies suggest that they have potential in the removal of heavy metals from polluted waters (DHIR et al., 2008; SOARES et al., 2008; WOLFF et al., 2009). However, some factors can limit the growth of Salvinia species, such as high $\mathrm{pH}$ (OWENS et al., 2005), anoxic conditions (JAMPEETONG; BRIX, 2009a) and salt stress (PARIDA; DAS, 2005). The last cited authors showed that salt excess affects various factors in these plants, including ion regulation, hormone levels, photosynthesis, leaf anatomy, lipid metabolism, and growth. In addition, chlorophyll and total carotenoid contents of leaves decrease in general due to increased salinity. An increase in proline content was observed in some aquatic macrophytes under salt stress (ROUT; SHAW, 1998; GOMES et al., 2011). Furthermore, salt enrichment causes morphological and nutritional disorders (GOMES et al., 2011), which alters availability, absorption and transport of nutrients within the plants (MUNNS; TESTER, 2008). 
High concentrations of $\mathrm{Na}^{+}$and $\mathrm{CI}^{-}$can cause toxicity in plants (CHINNUSAMY; ZHU, 2003), and these ions are present in greater quantities in seawater (MAKITA; HARATA, 2008). High salinity can alter ion accumulation, plant growth and leaf appearance and size in salt-sensitive species (WARWICK; BAILEY, 1997), whereas salt-tolerant ones are able to grow and reproduce even at oceanic salinities (MUNNS; TESTER, 2008). Some plants under salt stress are able to tolerate changes in environmental conditions. In these organisms, biochemical pathways promote water retention and uptake, which preserve photosynthesis and ionic homeostasis (ESTEVES; SUZUKI, 2008). When exposed to high concentrations of $\mathrm{NaCl}$, halophyte plants show increased levels of rubisco, although not all of this enzyme pool can be activated (GALMÉS et al., 2013).

Salvinia auriculata lacks true roots, having a rhizome with a stele U-shaped in cross section. The leaves are green to brown and oblong-elliptic to nearly circular. Its adaxial surface has elongated papillae, arranged in rows parallel to the main lateral veins (STOLZE et al., 1983). However, under the effects of high salinity, the older leaves can first become yellowgreen and then more brown, indicating a clear damage to leaves (THOUVENOT et al., 2012). The plants can occupy wetlands and lagoons with moderately saline waters and close to coasts (GOMES et al., 2011), with possible biomass variation regulated by season (KUFNER et al., 2011). This species is reported to occur in different sections of the Capibaribe River, showing large biomass in certain areas (XAVIER, 2014). This river is influenced by seawater up to $8 \mathrm{~km}$ upstream at high tide (CABRAL et al., 2004), and salinity may be an important factor determining the distribution of this species near the coast.

Therefore, it is important to understand the physiological mechanisms of tolerance and responses to salinity. In this work, we determined if salinity is a key factor regulating $S$. auriculata occurrence in the Capibaribe River. Accordingly, we evaluated the effects of seawater on photosynthetic activity and water content of the floating macrophyte $S$. auriculata, collected in a Capibaribe River reservoir, contributing to our understanding of the of distribution and abundance patterns of this species in coastal regions.

\section{Material and Methods}

\section{Plant collection and acclimation}

Salvinia auriculata Aubl. plants were collected from the oligotrophic Cursaí Reservoir of the Capibaribe River, situated in Paudalho, Pernambuco State. This reservoir is located in the mesoregion forest and northern forest microregion of Pernambuco. The region's climate exhibits tropical rainfall with dry summer and the rainy period during February to October, with mean annual precipitation of 1,634.2 mm (BELTRÃO et al., 2005). The water used was collected directly from the reservoir and seawater was obtained at Boa Viagem Beach, in Recife, Pernambuco (Figure 1).

FIGURE 1: Study area in Pernambuco State, Brazil. It includes the Capibaribe River, and also the Cursaí Reservoir (CUR), where the plants and freshwater were obtained. The seawater was obtained from Boa Viagem Beach.

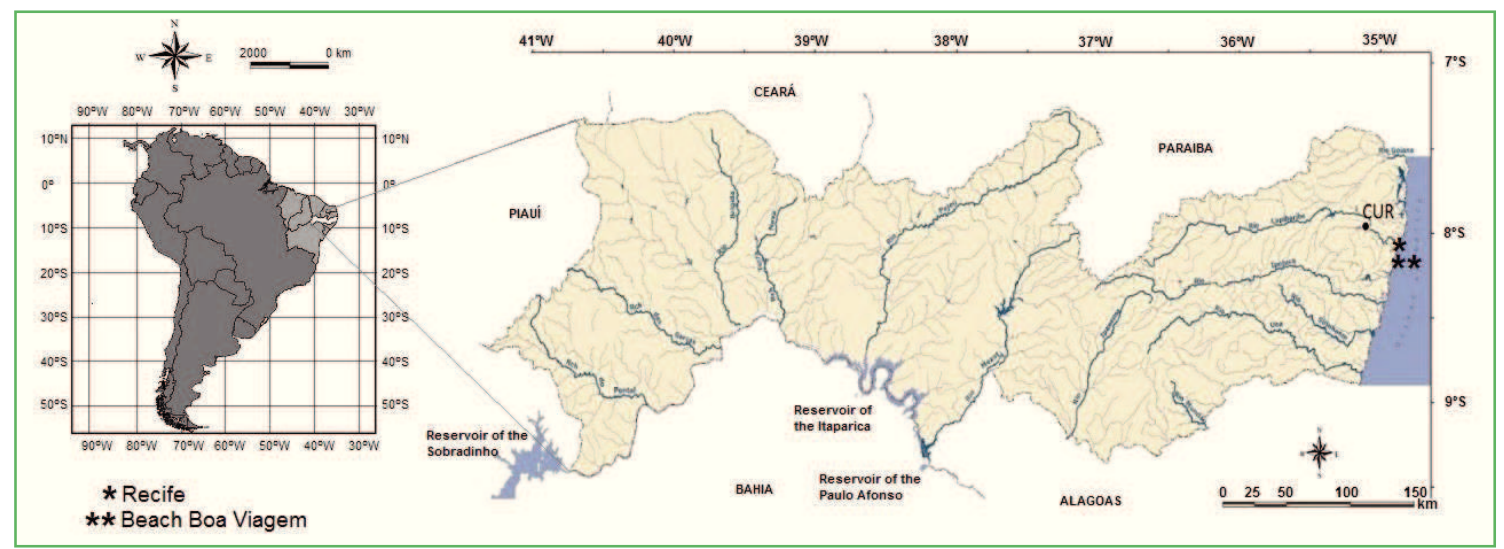


The plants were placed in 30 different glass containers of approximately $12 \mathrm{~cm}$ high x $8 \mathrm{~cm}$ wide. Each vessel had $250 \mathrm{~mL}$ of freshwater from the original sampling site. The specimens were standardized by fragments of $12.77 \pm 0.87 \mathrm{~g}$ fresh weight, each containing 6 aerial leaves. These plants were allowed to acclimate for $24 \mathrm{~h}$.

\section{Experimental design}

After the acclimation period, the water of each vessel was changed. Considering the series of 30 vessels, three different treatments were prepared (with 10 vessels per salinity treatment), filling the glass containers with $250 \mathrm{~mL}$ of water of different composition as follows: the first one with the reservoir freshwater at salinity of 0 at $25^{\circ} \mathrm{C}$ (similar to acclimation conditions, referred to as control), the second one with Boa Viagem Beach seawater at a salinity of 34 at $25^{\circ} \mathrm{C}$, and the third one with intermediate salinity, composed of 1:1 volume of freshwater:seawater, having a salinity of 17 at $25^{\circ} \mathrm{C}$. No nutritional enrichment was provided. Salinity was monitored during the whole experiment, and remained constant at these levels. This parameter was measured with a hand refractometer model NML 1280S.

Five of the 10 replicate vessels were randomly selected to obtain the different parameter measurements. The experimental unit consisted of each flask containing one plant fragment. The total number of flasks was 30 , although only 15 were utilized at each measurement moment. This procedure was performed to ensure a randomized experimental design. The experiment was conducted on July 23 to 27, 2012, totaling $40 \mathrm{~h}$.

Different water parameters were determined (temperature, salinity and dissolved oxygen), while others were done in the plants (fresh weight, chlorophyll $a$ fluorescence, $\mathrm{CO}_{2}$ balance and photosynthetic pigments). They were assessed during the experimental period, at the beginning $(0 \mathrm{~h})$ and after 20, 24, 28 and $40 \mathrm{~h}$. These measurement times were selected to allow detection of salinity effects, which can be recognized in short time periods (UPADHYAY; PANDA, 2005). These measurements are detailed below.

\section{Abiotic parameters}

All these parameters were measured in the water of each experimental treatment unit. Temperature $\left({ }^{\circ} \mathrm{C}\right)$ was assessed with a common thermometer. Water $\mathrm{pH}$ was measured with a DMPH-2 potentiometer. Dissolved and saturated oxygen levels in the water were analyzed with a Handylab OX1/SET oximeter. Oxygen data were obtained only at $20 \mathrm{~h}$ to the end of experiment.

\section{Photosynthesis from chlorophyll a fluorescence}

The photosynthetic performance of $S$. auriculata was evaluated by measuring the chlorophyll $a$ fluorescence with a pulse amplitude modulated (PAM) fluorometer (Diving-PAM underwater fluorometer; Walz, Effeltrich, Germany). The optimal equipment settings were previously evaluated for the species, and once defined, they were kept constant (gain=4 and measuring light intensity $=6$ PAM units). Initially, the samples were dark acclimated for $10 \mathrm{~min}$. Acclimation was necessary to obtain the maximal quantum yield of the sample. The photosynthetic measurements were performed using a ring-shaped adaptor to keep a constant distance between the sample and fiber optic sensor $(0.5 \mathrm{~cm}$ to $S$. auriculata). The procedures for rapid light curves (RLCs) are described below. After dark acclimation, the basal fluorescence amount was obtained $\left(F_{\mathrm{o}}\right)$, followed by a first saturating pulse (intensity $=8$ PAM units, i.e., about $4000 \mu \mathrm{mol}$ photons. $\mathrm{m}^{-2} \cdot \mathrm{s}^{-1}$, for $0.8 \mathrm{~s}$ ). The maximal fluorescence was then emitted by the samples, allowing calculation of the maximal quantum yield $\left(F_{\mathrm{v}} / F_{\mathrm{m}}\right)$, i.e., $F_{\mathrm{v}} / F_{\mathrm{m}}=\left(F_{\mathrm{m}}-F_{\mathrm{o}}\right) / F_{\mathrm{m}}$.

As mentioned above, these procedures were followed by performing the RLC option of the DivingPAM. This technique is a useful application in the rapid investigation of the photosynthetic apparatus providing information on the overall photosynthetic performance of photosynthetic organisms (WHITE; CRITCHLEY, 1999). The samples were exposed to eight increasing intensities of actinic light each for $5 \mathrm{~s}$, and each exposure was followed by a saturating light pulse, after which we measured $F_{\mathrm{t}}$ and $F_{\mathrm{m}}$, , respectively referring to steady state fluorescence and maximum fluorescence 
of the illuminated samples. These values allowed the calculation of effective quantum yield (Y(II)), i.e., $\mathrm{Y}(\mathrm{II})=\left(F_{\mathrm{m}}{ }^{2}-F_{\mathrm{t}}\right) / F_{\mathrm{m}}{ }$ ' (SCHREIBER et al., 1994) and the proper estimation of electron transport rates (ETR), where $\mathrm{ETR}=\mathrm{Y}(\mathrm{II}) * \mathrm{PAR} * \mathrm{~A} * \mathrm{~F}_{\mathrm{II}}$. A is absorptance, which was obtained by measuring the amount of light transmitted through a piece of plant $\left(E_{\mathrm{t}}\right)$ and the total light without this piece of plant $\left(E_{\mathrm{o}}\right)$. The same pieces that were used for RLC procedures were utilized to obtain these absorbance values, and A was determined as $\mathrm{A}=1-\left(E_{\mathrm{t}} / E_{\mathrm{o}}\right) . \mathrm{F}_{\mathrm{II}}$ (related to proportion of chlorophyll $a$ at PSII) was 0.5 (JOHNSEN; SAKHAUG, 2007).

To quantitatively compare RLCs using parametric statistics, two descriptive parameters were used: photosynthetic efficiency $\left(\alpha_{\mathrm{ETR}}\right)$ and maximum electron transport rate $\left(\mathrm{ETR}_{\max }\right)$. These parameters were calculated by fitting each ETR curve to the equation of Platt et al. (1980), following the Solver procedures suggested by Ritchie (2008).

\section{Infrared gas analyzer $-\mathrm{CO}_{2}$ balance}

The entire flasks containing all plant samples were individually placed under the CPY-4 Canopy Assimilation Chamber with $145 \mathrm{~mm}$ height x $146 \mathrm{~mm}$ (exposed diameter) and exposed area of $167 \mathrm{~cm}^{2}$. This chamber was connected to the EGM-4 Infrared gas analyzer (PPSystems), allowing analysis of $\mathrm{CO}_{2}$ flow in a closed system. Samples remained in the chamber for 2 min and $\mathrm{CO}_{2}$ amounts were recorded every $5 \mathrm{~s}$.

The carbon flux was calculated using the following formula (TAGESSON, 2006): $\mathrm{C}_{\text {flux }}=\left(\left(\mathrm{C}_{\text {final }}-\mathrm{C}_{\text {initial }}\right) * \mathrm{t}^{-1} *\right.$ $\left.\left.\left(\mathrm{V}_{\mathrm{ch}} * \mathrm{~A}_{\mathrm{ch}}{ }^{-1}\right)\right)^{*} 0.007436 * 0.1584\right) / \mathrm{FW}$, where $\mathrm{C}_{\text {flux }}$ is the carbon flux, $\mathrm{C}_{\text {final }}$ and $\mathrm{C}_{\text {initial }}$ are the amount of $\mathrm{C}$ determined at the beginning and end of the incubation period, $\mathrm{V}_{\mathrm{ch}}$ is the chamber volume, $\mathrm{A}_{\mathrm{ch}}$ is the chamber exposed area, and FW is the fresh weight of the samples immediately after measuring $\mathrm{C}_{\text {flux }}$.

The carbon flux unit was $\mathrm{g} \mathrm{CO}_{2} \mathrm{~m}^{-2} \mathrm{~h}^{-1} \mathrm{~g}^{-1}$.

\section{Growth rates}

Fresh weights were obtained from samples directly at the beginning and end of the experiment (after $40 \mathrm{~h}$ ).
The plants were pre-dried with absorbent paper and then weighed on an analytical balance (BEL Equipment LTDA). Initial $\left(\mathrm{FW}_{\mathrm{i}}\right)$ and final $\left(\mathrm{FW}_{\mathrm{f}}\right)$ fresh weights were used to determine relative growth rate (RGR) according to Kain (1987): $\mathrm{RGR}=\left[\left(\ln \mathrm{FW}_{\mathrm{f}} / \mathrm{ln}\right.\right.$ $\left.\left.\mathrm{FW}_{\mathrm{i}}\right) * \mathrm{t}-1\right] * 100$.

On the last experimental day, samples were weighed and placed in an oven until dry $\left(70^{\circ} \mathrm{C}\right)$, to determine dry weight (DW) and proportions FW and DW.

\section{Pigments}

Photosynthetic pigments were extracted from samples in the beginning and at the end of the experimental period $(40 \mathrm{~h})$ for all treatments. Samples were frozen in liquid nitrogen, and chlorophyll $a$, chlorophyll $b$ and total carotenoids were extracted and quantified with $80 \%$ acetone according to Lichtenthaler (1987).

\section{Statistics}

All biotic parameters were statistically evaluated. This was done by two-way analysis of variance (ANOVA), where the evaluated factors were salinity and time. Previously, data were tested for normality and homogeneity of variances (Cochran test). When statistical effects were detected (significance level of $0.05 \%$ ), data were treated with a Student-Newman-Keuls a posteriori test for multiple comparisons.

\section{Results}

\section{Abiotic parameters}

There was a decrease in dissolved oxygen in the flask water. From values around $2 \mathrm{mg} . \mathrm{L}^{-1}$ in the three different conditions, there was a four times reduction, where a salinity of 34 was used (Figure 2A). Water flask temperatures ranged from 25 to $30^{\circ} \mathrm{C}$. However, these variations occurred similarly for the three experimental conditions (Figure 2B). 
FIGURE 2: Dissolved oxygen and water temperature variation during an experimental period of $42 \mathrm{~h}$, at three salinity treatments $(0,17$ and 34) for Salvinia auriculata. A. Dissolved oxygen values. B. Temperature values. Data are presented as mean and standard deviation. $\mathrm{N}=5$.

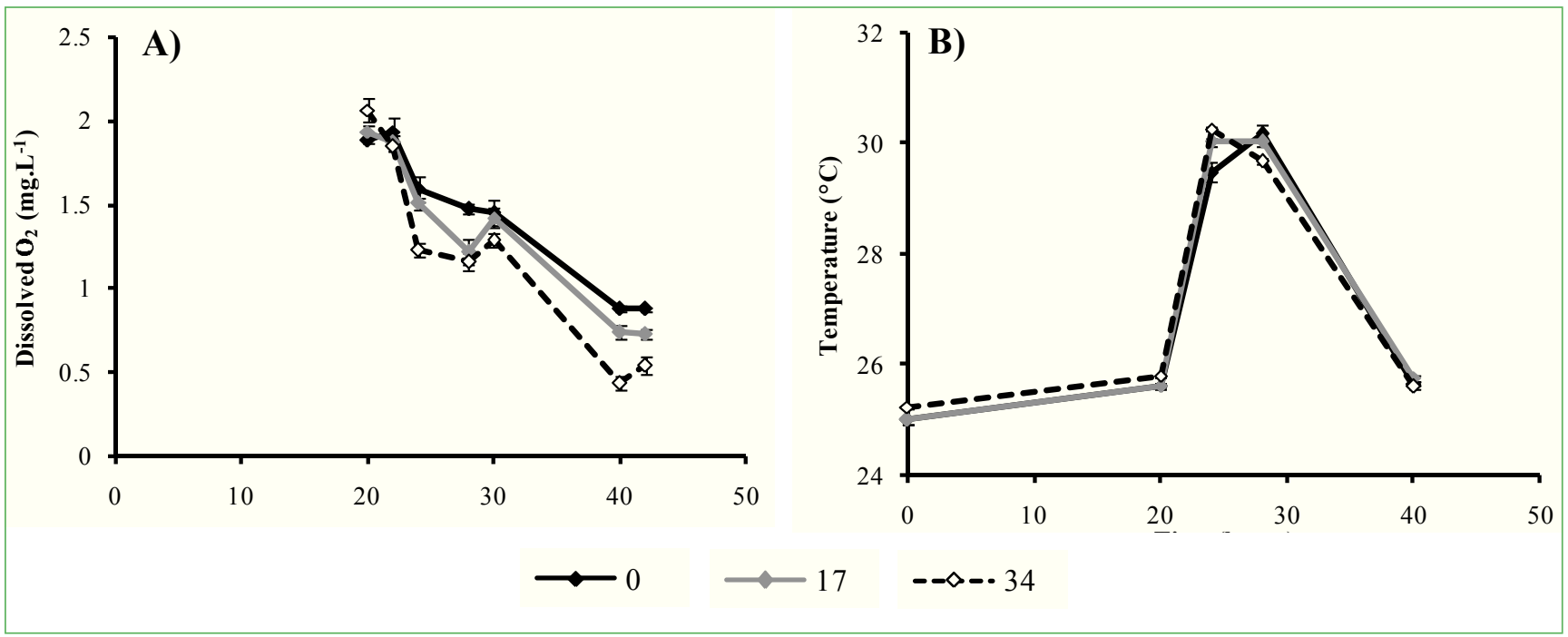

\section{Biotic responses}

Salvinia auriculata was strongly affected by salinity treatments. Plants showed alterations in color after $40 \mathrm{~h}$ of treatments, in comparison to those maintained under freshwater treatment, with green leaves (Figure 3A). The altered plants showed greenbrownish colored leaves at salinity 17 and completely dark-brown leaves with seawater (salinity 34) (Figure 3B,C). Growth rates and chlorophyll contents, analyzed regardless of the time, were affected statistically by this factor (Table 1). Growth rate was predominantly negative for treated samples at $40 \mathrm{~h}$. While for control samples, it was not less than $-0.5 \% \cdot \mathrm{h}^{-1}$, the decrease in growth and biomass amount was pronounced in salinity treatments, statistically similar and with negative growth rates around $-1.2 \% \cdot \mathrm{h}^{-1}$ (Figure 3D).

TABLE 1: Results of two-way ANOVA showing isolated and interactive effects between independent variables (salinity and time). Dependent variable data were obtained for Salvinia auriculata cultivated for $40 \mathrm{~h}$ in a greenhouse under different salinities. Bold values indicate significant data, considering a $95 \%$ confidence interval $(\alpha<0.05)$. $\mathrm{N}=5$. $\mathrm{x}=$ variable not analyzed.

\begin{tabular}{lcccccc}
\hline \multirow{2}{*}{ Dependent variable } & \multicolumn{2}{c}{ Salinity (1) } & \multicolumn{2}{c}{ Time (2) } & \multicolumn{2}{c}{ (1) x (2) } \\
\cline { 2 - 7 } & $\boldsymbol{F}$ & $\boldsymbol{p}$ & $\boldsymbol{F}$ & $\boldsymbol{P}$ & $\boldsymbol{F}$ & $\boldsymbol{p}$ \\
\hline Growth Rate $\left(\% \mathrm{~h}^{-1}\right)$ & $\mathbf{1 3 . 2 4}$ & $\mathbf{0 . 0 0}$ & $\mathrm{x}$ & $\mathrm{x}$ & $\mathrm{x}$ & $\mathrm{x}$ \\
$\alpha_{\mathrm{ETR}}$ & 1.92 & 0.16 & 0.46 & 0.71 & 0.70 & 0.65 \\
$\mathrm{ETR}_{\max }\left(\mu \mathrm{mol} \mathrm{electrons} \mathrm{m}^{-2} \mathrm{~s}^{-1}\right)$ & $\mathbf{2 8 . 8 8}$ & $\mathbf{0 . 0 0}$ & 2.20 & 0.10 & $\mathbf{4 . 7 1}$ & $\mathbf{0 . 0 0}$ \\
$\mathrm{CO}_{2}\left(\mathrm{~g} \mathrm{~m}^{-2} \mathrm{~h}^{-1} \mathrm{~g} \mathrm{plt}^{-1}\right)$ & 0.58 & 0.57 & $\mathbf{3 . 7 3}$ & $\mathbf{0 . 0 2}$ & 1.17 & 0.34 \\
$F_{\mathrm{v}} F_{\mathrm{m}}$ & $\mathbf{7 . 1 7}$ & $\mathbf{0 . 0 1}$ & $\mathbf{3 . 9 9}$ & $\mathbf{0 . 0 1}$ & $\mathbf{2 . 7 5}$ & $\mathbf{0 . 0 1}$ \\
${\text { Chlorophyll } a\left(\mathrm{mg} \mathrm{gDW}^{-1}\right)}_{\text {Chlorophyll } b\left(\mathrm{mg} \mathrm{gDW}^{-1}\right)}$ & $\mathbf{1 7 . 3 9}$ & $\mathbf{0 . 0 0}$ & $\mathrm{x}$ & $\mathrm{x}$ & $\mathrm{x}$ & $\mathrm{x}$ \\
\hline
\end{tabular}


FIGURE 3: Visual symptoms of toxicity and growth rates of Salvinia auriculata after $40 \mathrm{~h}$ of cultivation under different salinity treatments. A. Plants under salinity of 0 (control). B. Plants under salinity of 17 . C. Plants under salinity of 34 . Scale bar: $0.83 \mathrm{~cm}$; D. Growth rates $\left(\% \cdot \mathrm{h}^{-1}\right)$ of $S$. auriculata from initial to $40 \mathrm{~h}$ of different salinity treatments. Data are means $\pm \mathrm{SD}$. $\mathrm{N}=5$.
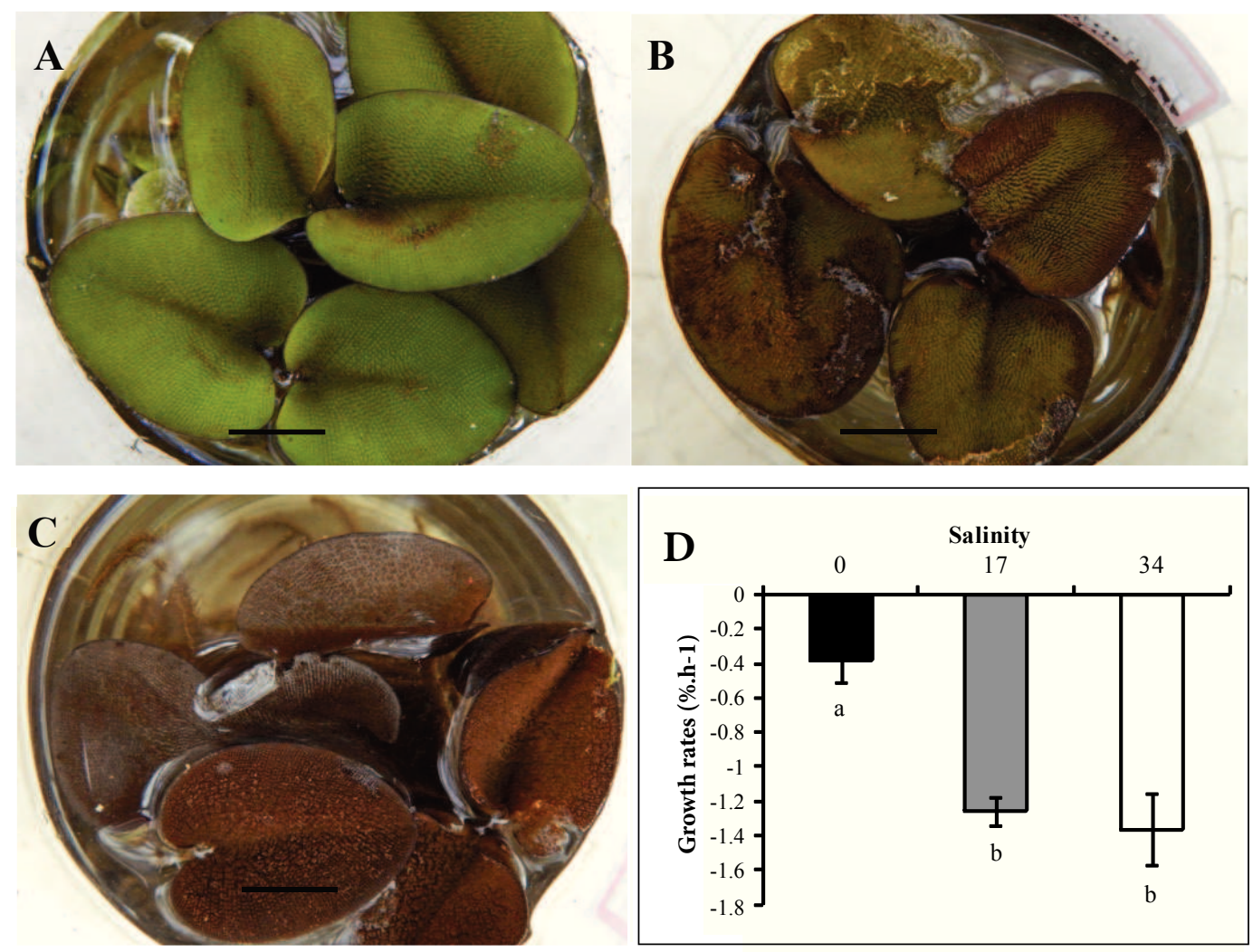

Chlorophyll content of S. auriculata remained constant with both treatments of increased salinity in comparison to initial pigment content in the plant, while it increased in samples maintained in freshwater (Figure 4A). The same response pattern was observed for chlorophyll $a$ and chlorophyll $b$ contents.

Photosynthesis of $S$. auriculata was differently affected by salinity and time. While photosynthetic efficiency $\left(\alpha_{\text {ETR }}\right)$ was not affected by either of these factors (and their interaction), $F_{\mathrm{v}} / F_{\mathrm{m}}$ was highly influenced by them, and ETR ${ }_{\max }$ values were only affected by salinity and the interaction of this factor with time (Table 1).

Although there was a small decrease in $F_{\mathrm{v}} / F_{\mathrm{m}}$ values for $S$. auriculata after $24 \mathrm{~h}$ under control conditions, these variations were not significant (freshwater, without addition of seawater). At the end of the experimental period, the plants showed similar values of $F_{\mathrm{v}} / F_{\mathrm{m}}$ in

comparison to initial ones, remaining around 0.8 . On the other hand, when samples were exposed to a salinity of 17, this trend was also observed, but without reaching values as high as initial ones, and $F_{\mathrm{v}} / F_{\mathrm{m}}$ was close to 0.6 from $20 \mathrm{~h}$ till the end. Finally, if treated with salinity of $34, F_{\mathrm{v}} / F_{\mathrm{m}}$ of these plants was reduced gradually, till reaching significantly lower values after $40 \mathrm{~h}$ in comparison to those samples which remained under salinity of 0 during the same period (Figure 4B).

Other two photosynthetic parameters evaluated showed different response patterns. Salinity and experimental period factors did not caused any significant variation in $\alpha_{\mathrm{ETR}}$ (Figure 4C). However, in the case of $\mathrm{ETR}_{\max }$, there was an initial increase to control samples after $20 \mathrm{~h}$ of exposure under greenhouse conditions with freshwater (salinity of 0 ). However, in following hours, these values decreased again, reaching the same maximal electron transport rates of around 30 $\mu \mathrm{mol}$ electrons. $\mathrm{m}^{-2} . \mathrm{s}^{-1}$. In treatments with addition of 
FIGURE 4: Photosynthetic responses of Salvinia auriculata maintained under different salinity conditions (freshwater 0 , 17 and 34 ) during $40 \mathrm{~h}$ in a greenhouse. A. Photosynthetic pigments (chlorophyll $a$ and chlorophyll $b$ ) of $S$. auriculata at the beginning and after $40 \mathrm{~h}$ of experiment. Different letters (lowercase for chlorophyll $a$, and uppercase for chlorophyll $b$ content) represent statistical difference according to Student-Newman-Keuls test. B. Maximum quantum yield $\left(F_{\mathrm{v}} / F_{\mathrm{m}}\right)$. C. Photosynthetic efficiency $\left(\alpha_{\mathrm{ETR}}\right)$. D. Maximum electron transport rates $\left(\mathrm{ETR}_{\max }\right)$. For all photosynthetic responses, data are means $\pm \mathrm{SD} . \mathrm{N}=5$.

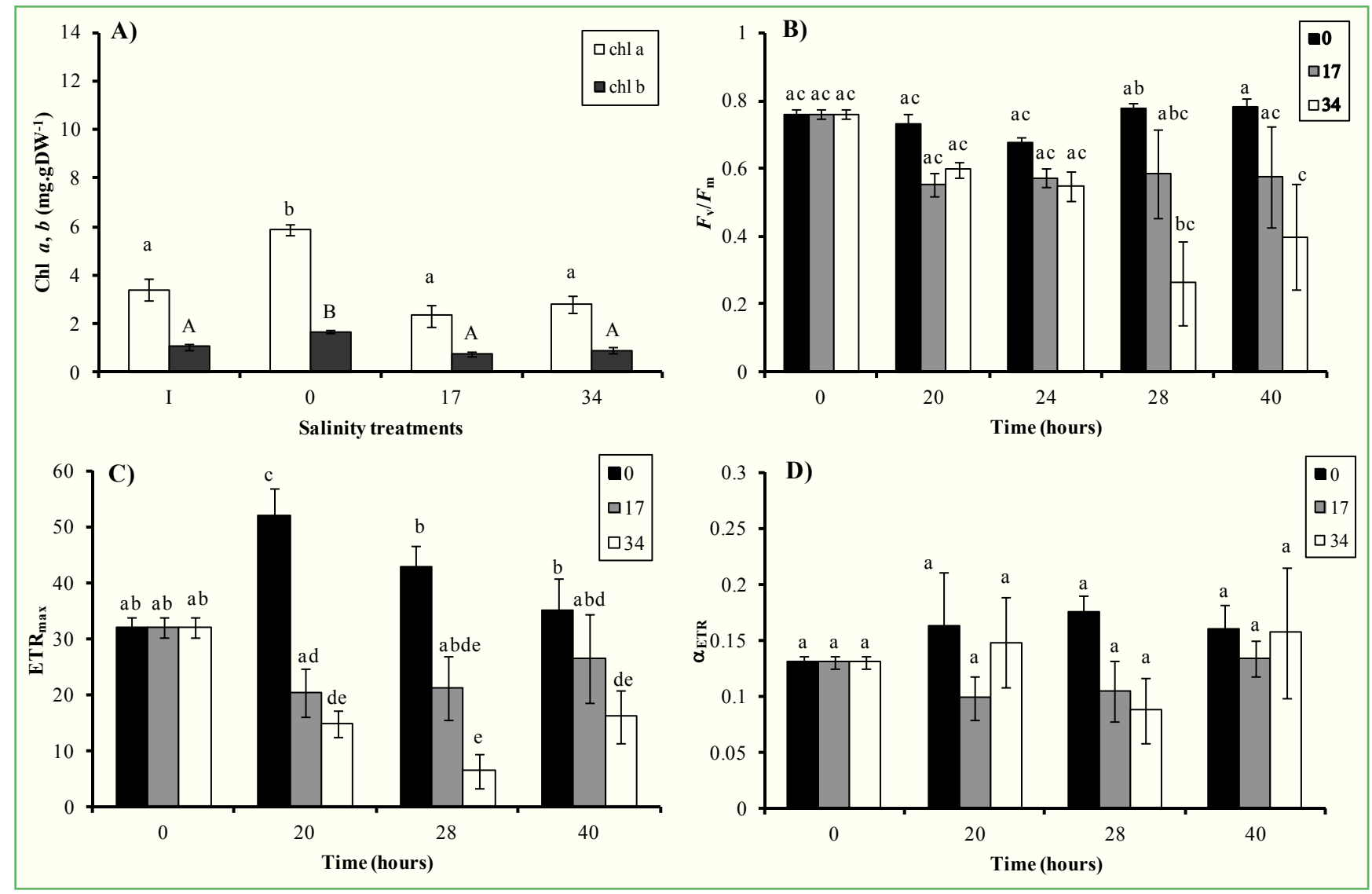

seawater (salinities of 17 and 34), there was an initial reduction in these rates, followed by a recovery, and they were lower than control but statistically similar. With salinity of 34 , the plants showed the lowest ETR ${ }_{\max }$, but this same treatment resulted in plants with statistically similar values compared to the control condition at the end of experimental period (Figure 4D).

$\mathrm{CO}_{2}$ fluxes of $S$. auriculata varied only with time (Table 1). However, post hoc tests showed no differences in paired comparison between all different conditions and time periods of measurements. A decreasing trend was observed for samples exposed to salinities of 0 and 17 , while at 34 , an initial decline was recorded, followed by sharp variation until reaching the lowest $\mathrm{CO}_{2}$ flux values (Figure 5).
FIGURE 5: $\mathrm{CO}_{2}$ fluxes of Salvinia auriculata maintained under different salinity conditions (freshwater 0, 17 and 34) for $40 \mathrm{~h}$ in a greenhouse. Data are means $\pm \mathrm{SD}$. $\mathrm{N}=5$.

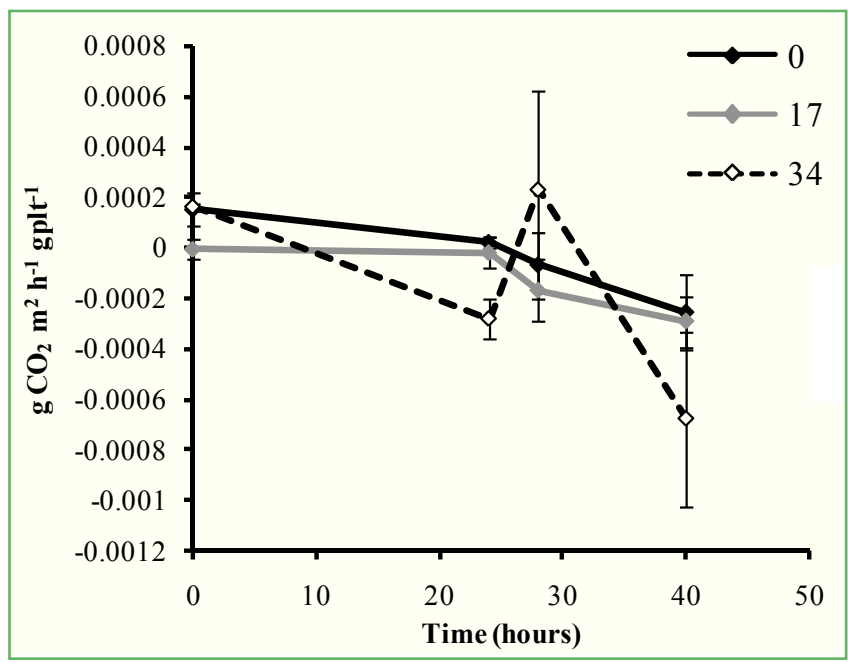




\section{Discussion}

Salvinia auriculata was affected by salinity over a short time period $(40 \mathrm{~h})$. These rapid responses may explain the reason why this species is absent from the coastal region of the Capibaribe River, where salinity variations occur. The decrease in photosynthesis and growth rate under highest salinity can help to explain the reasons why the species does not occur in high saline waters, but some tolerance to intermediate values was detected. Non-halophytic macrophytes can show a decline in growth when subjected to a high salinity (WARWICK; BAILEY, 1997). In a previous work, $S$. natans appeared to be tolerant to intermediate salinity but was significantly affected by high $\mathrm{NaCl}$ levels, due to osmotic stress (JAMPEETONG; BRIX, 2009b), similarly to what was observed in $S$. auriculata here.

Dissolved oxygen in the water containing $S$. auriculata decreased over time under all conditions. However, with higher salinity treatment, this parameter reached the lowest values. Photosynthesis removes carbon dioxide from the water while producing oxygen as a by-product. If water does not have a source for replacing oxygen, dissolved oxygen will decline (OWENS et al., 2005). A deficiency of $\mathrm{O}_{2}$ may have a negative effect on plant metabolism including nitrogen uptake and assimilation (GIBBS; GREENWAY, 2003; MORARD et al., 2004; JAMPEETONG; BRIX, 2009a). This is important when considering that $S$. auriculata had a biomass loss, even in the control treatment. The biomass loss was more pronounced in plants under salinities of 17 and 34. Considering their floating behavior, macrophytes can show rapid nutrient uptake (BIBER, 2009), the absence of nutrient input at the beginning of the experiment can explain biomass loss in all treatments. Salvinia auriculata was subjected to a eutrophicated system before the experiment because the Capibaribe River receives frequent nutrient discharge due to industrial pollution (FLORES MONTES et al., 2011). When subjected to nutrient addition, macrophytes can exhibit an increase in biomass, while at the highest salinity the opposite would be true (MACEK; REJMÁNKOVÁ, 2007).

Elevated concentrations of $\mathrm{NaCl}$ on the outside of the roots may have decreased the water potential in S. auriculata. Therefore, when the water extraction potential of the roots is affected, high concentrations of $\mathrm{Na}^{+}$and $\mathrm{CI}^{-}$in the plant cells have negative effects on various enzymatic processes (JAMPEETONG; BRIX, 2009b). High salinity levels limit leaf or shoot growth of plants (MACEK; REJMÁNKOVÁ, 2007). It was observed that the leaves of $S$. auriculata tended to lose their original color, becoming brownish at the end of seawater treatment. Similar results were observed for Ludwigia grandiflora, an invasive macrophyte, with older leaves first becoming yellow-green and then brown at high salinity treatment (THOUVENOT et al., 2012). In addition, micro morphology alterations were detected by Gomes et al. (2011) in S. auriculata exposed to saline treatments, which caused changes in chloroplast membranes, emergence of rounded starch grains and progressive loss of trichome turgor, with alterations in leaf anatomy, showing rough appearance.

When plants received any salinity increment, chlorophyll content remained similar to that observed at the beginning of experimental period (initial values). However, in a previous work, the content of chlorophyll- $a$, chlorophyll- $b$ and total chlorophyll (chlorophyll- $a+b$ ) in $S$. auriculata decreased when the plants were subjected to saline treatments (100 and $200 \mathrm{mM} \mathrm{NaCl} ; 100$ and $200 \mathrm{mM} \mathrm{Na}_{2} \mathrm{SO}_{4}$ ) (GOMES et al., 2011). This same situation was detected in Salvinia molesta by increasing $\mathrm{NaCl}$ concentration, with reductions in chlorophyll and carotenoid contents after 3 days (UPADHYAY; PANDA, 2005). Salt stress also affected the chlorophyll accumulation of Holocylon persicum, Tamarix ramosissima, and Calligonum leucocladum in a Chinese study (XINWEN et al., 2008). It is possible that plants transported to the university greenhouse were exposed to lower amounts of light than under natural reservoir conditions. This could have triggered an increase in pigment content of plants (shadow effect). Shadow plants have more pigments to optimize the absorption of lower amounts of light that reaches their leaves. Therefore, the greenhouse could have an effect similar to that when keeping plants under low light environments, where chlorophyll content increased under the conditions designed as control, without salinity increment. The addition of salt to the water counteracted this effect, preventing an increase in 
pigment. These variations under pigment contents were directly related to photosynthetic responses measured by chlorophyll fluorescence. Photosynthetic responses such as $F_{\mathrm{v}} / F_{\mathrm{m}}$ of $S$. auriculata were influenced by time and salinity, while ETR max $_{\text {ax }}$ values were affected by salinity and the interaction of this factor with time. When $S$. auriculata individuals were kept under anoxic conditions, they showed lower levels of chlorophyll and ETR $_{\max }$ and $\mathrm{F}_{\mathrm{v}} / \mathrm{F}_{\mathrm{m}}$ (JAMPEETONG; BRIX, 2009a). This anoxic situation can explain the same responses obtained in our study.

While fluorescence parameters in $S$. auriculata showed clear effects of salinity treatments, $\mathrm{CO}_{2}$ flux was not affected. Thus, it is possible to conclude that salinity affected photosynthetic routes related to photochemical capture, while carbon metabolism did not seem to have been affected, since $\mathrm{CO}_{2}$ flux was similar under all conditions, with only a trend toward lower flux values under higher salinity treatments. The effects of salinity on plant photochemical responses have been reported in the literature, where $\mathrm{ETR}_{\max }$ and $F_{\mathrm{v}} / F_{\mathrm{m}}$ were significantly lower in plants treated with 100 and $150 \mathrm{mM}$ salinity in comparison with plants maintained under control conditions (JAMPEETONG; BRIX, 2009a; 2009b).

Salvinia auriculata undergoes morphological and physiological alterations that make it unable to develop and grow in mesohaline or euryhaline environments (GOMES et al., 2011). This was corroborated by the results of our study, which showed important physiological changes in a plant that occurs in environments with brackish water influence, like the Capibaribe River. This can help to explain why in a previous study Salvinia biomass was higher in areas with little or no influence of seawater. Salvinia auriculata biomass dynamics was studied by Xavier (2014) along the Capibaribe River, with higher values of biomass (up to $50.51 \mathrm{gDW} / \mathrm{m}^{2}$ ) being observed in an area classified as hypereutrophic, with high concentration of phosphorous and without brackish water influence. According to that study, estuarine areas did not have a substantial abundance of $S$. auriculata.

In conclusion, this study provides physiological explanation for the absence of $S$. auriculata in estuarine and salt waters influenced areas of the Capibaribe River, as this species presented very significant negative effects in a short time period of exposure to intermediate and high saline waters. This may be a primary factor controlling the distribution and abundance of S. auriculata in coastal regions.

\section{Acknowledgements}

We thank the Post-Graduation Program of Botany of the Federal Rural University of Pernambuco, which allowed us to host visiting professor J.B.B and develop a course that was instrumental to conducting this study. Dr. A. Leyva (USA) helped with English editing of the manuscript.

\section{References}

BELTRÃO, B. A.; SOUZA-JUNIOR, L. C.; GALVÃO, M. J. T. G.; PEREIRA, S. N.; MIRANDA, J. L. F. (Org.). Projeto cadastro de fontes de abastecimento por água subterrânea, estado de Pernambuco: relatório diagnóstico do município de Paudalho. Recife: CPRM, 2005. 11 p.

BIBER, P. Determining salinity-tolerance of giant Salvinia using chlorophyll fluorescence. Gulf Caribbean Research, Hattiesburg, v. 21, p. 31-36, 2009

BINI, L. M.; THOMAZ, S. M.; MURPHY, K. J.; CAMARGO, A. F. M. Aquatic macrophyte distribution in relation to water and sediment conditions in the Itaipu Reservoir, Brazil. Hydrobiologia, Brussels, v. 415, p. 147-154, 1999.

CABRAL, J. J. S. P.; MONTENEGRO, S. M. G. L.; PAIVA, A. L. R.; FARIAS, V. P. Groundwater salinization in the central region of Recife (Brazil) due to brackish water in Capibaribe river at high tide. In: SWIM, 18, 2004, Cartagena. Resumos... Cartagena: SWIM , 2004. p. 717-727.

CHINNUSAMY, V.; ZHU, J.-K. Plant salt tolerance. Topics calcium-binding protein SOS3. Proceedings of the National Academy of Sciences of the United States of America, Current Genetics, Washington, v. 4, p. 241-270, 2003.

DESMET, N. J. S.; VAN-BELLEGHEM, S.; SEUNTJENS, P.; BOUMA, T. J.; BUIS, K.; MEIRE, P. Quantification of the impact of macrophytes on oxygen dynamics and nitrogen retention in a vegetated lowland river. Physics Chemistry Earth, Atlanta, v. 36, p. 479-489, 2011.

DINIZ, C. R.; CEBALLOS, B. S. O.; BARBOSA, J. E. L.; KONIG, A. Uso de macrófitas aquáticas como solução ecológica para melhoria da qualidade da água. Revista Brasileira de Engenharia Agrícola Ambiental, Campina Grande, v. 9, p. 226-230, 2005.

DHIR, B.; SHARMILA, P.; SARADHI, P. P. Photosynthetic performance of Salvinia natans exposed to chromium and zinc rich 
wastewater. Brazilian Journal of Plant Physiology, Campos dos Goytacazes, v. 20, p. 61-70, 2008.

ESTEVES, F. A. Fundamentos de limnologia. Rio de Janeiro: Interciência/FINEP, 1998. 602 p.

ESTEVES, F. A.; CAMARGO, A. F. M. Sobre o papel das macrófitas aquáticas na estocagem e cicalgem de nutrientes. Acta Limnologica Brasiliensia, Botucatu, v. 1, p. 273-298, 1986.

ESTEVES, S.; SUZUKI, M. S. Efeito da salinidade sobre as plantas. Oecologia Brasiliensis, Rio de Janeiro, v. 12, p. 662-679, 2008.

FLORES MONTES, M. J.; PAULO, J. H.; NASCIMENTO FILHO, G. A.; GASPAR, F. L.; FEITOSA, F. A.; SANTOS-JÚNIOR, A. C.; BATISTA, T. N. F.; TRAVASSOS, R. K.; PITANGA, M. E. The trophic status of an urban estuarine complex in Northeast Brazil. Journal of Coastal Research, Fort Lauderdale, v. 64, p. 408-411, 2011.

GALMÉS, J.; ARANJUELO, I.; MEDRANO, H.; FLEXAS, J. Variation in Rubisco content and activity under variable climatic factors. Photosynthesis Research, Dordrecht, v. 117, p. 73-90, 2013.

GARDNER, J. L.; AL-HAMDANI, S. H. Interactive effects of aluminum and humic substances on Salvinia. Journal of Aquatic Plant Manage, Gainesville, v. 35, p. 30-34, 1997.

GIBBS, J.; GREENWAY, H. Mechanisms of anoxia tolerance in plants. I. Growth, survival and anaerobic catabolism. Functional Plant Biology, Clayton South Vic, v. 30, p. 1-47, 2003.

GOMES, M. A. C.; SUZUKI, M. S.; CUNHA, M.; TULLII, C. F. Effect of salt stress on nutrient concentration, photosynthetic pigments, proline and foliar morphology of Salvinia auriculata Aubl. Acta Limnologica Brasiliensia, Botucatu, v. 23, p. 164-176, 2011.

JAMPEETONG, A.; BRIX, H. Oxygen stress in Salvinia natans: Interactive effects of oxygen availability and nitrogen source. Environmental Experiment Botany, Amsterdam, v. 66, p. 153159, 2009a.

JAMPEETONG, A.; BRIX, H. Effects of $\mathrm{NaCl}$ salinity on growth, morphology, photosynthesis and proline accumulation of Salvinia natans. Aquatic Botany, Gainesville, v. 91, p. 181-186, 2009 b.

JOHNSEN, G.; SAKSHAUG, E. Biooptical characteristics of psii and psi in 33 species (13 pigment groups) of marine phytoplankton, and the relevance for pulse-amplitude-modulated and fastrepetition-rate fluorometry. Journal of Phycology, Moss Landing, v. 43, p. 1236-1251, 2007.

KAIN, J. M. Seasonal growth and photoinhibition in Plocamium cartilagineum (Rhodophyta) off the Isle of Man. Phycologia, Sydney, v. 26, p. 88-99, 1987.

KLUMPP, A.; BAUER, K.; FRANZ-GERSTEIN, C.; MENEZES, M. D. Variation of nutrient and metal concentrations in aquatic macrophytes along the rio Cachoeira in Bahia (Brazil). Environmental International, Amsterdam, v. 28, p. 165-171, 2002. KUFNER, D. C. L.; SCREMIN-DIAS, E.; GUGLIERICAPORAL, A. Composição florística e variação sazonal da biomassa de macrófitas aquáticas em lagoa de meandro do Pantanal. Rodriguésia, Rio de Janeiro, v. 62, p. 803-812, 2011.

LICHTENTHALER, H. K. Chlorophylls and carotenoids: pigments of photosynthetic biomembranes. Methods of Enzymology, Amsterdam, v. 148, p. 350-382, 1987.
MACEK, P.; REJMÁNKOVÁ, E. Response of emergent macrophytes to experimental nutrient and salinity additions. Functional Ecology, London, v. 21, p. 478-488, 2007.

MAKITA, M.; HARATA, A. Photocatalytic decolorization of rhodamine $\mathrm{B}$ dye as a model of dissolved organic compounds: influence of dissolved inorganic chloride salts in seawater of the Sea of Japan. Chemical Engineering Processes: Process Intensification, Amsterdam, v. 20, p. 859-863, 2008.

MORARD, P.; LACOSTE, L.; SILVESTRE, J. Effect of oxygen deficiency on mineral nutrition of excised tomato roots. Journal of Plant Nutrition, Philadelphia, v. 27, p. 613-624, 2004.

MUNNS, R.; TESTER, M. Mechanisms of salinity tolerance. Annual Review of Plant Biology, Palo Alto, v. 59, p. 651-681, 2008.

OWENS, C. S.; SMART, R. M.; HONNELL, D. R.; DICK, G. O. Effects of $\mathrm{pH}$ on growth of Salvinia molesta Mitchell. Journal of Aquatic Plant Manage, Gainesville, v. 43, p. 34-38, 2005.

PARIDA, A. K.; DAS, A. B. Salt tolerance and salinity effects on plants: a review. Ecotoxicology, Environment and Safety, Amsterdam, v. 60, p. 324-349, 2005.

PLATT, T.; GALLEGOS, C. L.; HARRISON, W. G. Photoinhibition of photosynthesis in natural assemblages of marine phytoplankton. Journal of Marine Research, New Haven, v. 38, p. 687-701, 1980. RIGOLLET, V.; SFRISO, A.; MARCOMINI, A.; CASABIANCA, M. L. Seasonal evolution of heavy metal concentrations in the surface sediments of two Mediterranean Zostera marina L. beds at Thau lagoon (France) and Venice lagoon (Italy). Bioresources Technology, Oxford, v. 95, p. 159-167, 2004.

RITCHIE, R. J. Fitting light saturation curves measured using modulated fluorometry. Photosynthesis Research, Dordrecht, v. 96, p. 201-215, 2008.

ROUT, N. P.; SHAW, B. P. Salinity tolerance in aquatic macrophytes: probable role of proline, the enzymes involved in its synthesis and C4 type of metabolism. Plant Sciences, Davies, v. 136, p. 121-130, 1998.

SCHREIBER, U.; BILGER, W.; NEUBAUER, C. Chlorophyll fluorescence as a non-intrusive indicator for rapid assessment of in vivo photosynthesis. In: SCHULZE, E. D.; CALDWELL, M. M. (Ed.). Ecophysiology of photosynthesis. Ecological Studies. Vol. 100. Berlin: Springer, 1994. p. 49-70.

SOARES, D. C. F.; OLIVEIRA, E. F.; SILVA, G. D. D. F.; DUARTE, L. P.; POTT, V. J.; VIEIRA FILHO, S. A. Salvinia auriculata: aquatic bioindicator studied by instrumental neutron activation analysis (INAA). Applied Radiation Isotopes, Amsterdam, v. 66, p. 561-564, 2008.

STOLZE, R. G.; OLLGAARD, B.; HICKEY, R. J. Ferns and fern allies of Guatemala. Part III. Marsileaceae, Salviniaceae, and the fern allies (including a comprehensive index to Parts I, II and III). Vol. 12. 1983. 91 p.

TAGESSON, T. Calibration and analysis of soil carbon efflux estimates with closed chambers at Forsmark and Laxemar. Lund: Department of Physical Geography and Ecosystem Analysis, University Lund. SKB Rapport R-06-125, 2006. 36 p.

THOMÉ, L. C. P. Bioacumulação de íons de $\mathbf{P b}^{+\mathbf{2}}$ na macrófita Salvinia auriculata. 2008. 96 f. Dissertação (Mestrado em Engenharia Química) - Universidade Estadual do Oeste do Paraná, Toledo. 2008. 
THOUVENOT, L.; HAURY, J.; THIÉBAUT, G. Responses of two invasive macrophyte species to salt. Hydrobiologia, Brussels, v. 686, p. 213-223, 2012.

TRINDADE, C. R. T. Biomassa, produtividade e nutrientes de Salvinia herzogii de la Sota e Azolla filiculoides Lam., em dois corpos d'água rasos subtropicais (Rio Grande, RS-Brasil). 2008. 75 f. Dissertação (Mestrado em Biologia de Ambientes Aquáticos Continentais) - Universidade Federal do Rio Grande, Rio Grande. 2008.

UPADHYAY, R. K.; PANDA, S. K. Salt tolerance of two aquatic macrophytes, Pistia stratiotes and Salvinia molesta. Biologia Plantarum, Praha v. 49, p. 157-159, 2005.

WARWICK, N. W. M.; BAILEY, P. C. E. The effect of increasing salinity on the growth and ion content of three non-halophytic wetland macrophytes. Aquatic Botany, Gainesville, v. 58, p. 7388, 1997.

WHITE, A. K.; CRITCHLEY, C. Rapid light curves: a new fluorescence method to assess the state of the photosynthetic apparatus. Photosynthesis Research, Dordrecht, v. 59, p. 63-72, 1999.
WOLFF, G.; ASSIS, L. R.; PEREIRA, G. C.; CARVALHO, J. G.; CASTRO, E. M. Efeitos da toxicidade do zinco em folhas de Salvinia auriculata cultivadas em solução nutritiva. Planta Daninha, Viçosa, v. 27, p. 133-137, 2009.

XAVIER, L. R. C. C. Efeitos da urbanização sobre a composição e estrutura das comunidades de macrófitas aquáticas ao longo do Rio Capibaribe - Pernambuco - Brasil. 2014. $70 \mathrm{f}$. Dissertação (Mestrado em Botânica) - Universidade Federal Rural de Pernambuco, Recife. 2014.

XINWEN, X. U.; HAILIANG, X. U.; YANLING, W.; XIAOJING, W.; YONGZHI Q. I. U.; BO, X. U. The effect of salt stress on the chlorophyll level of the main sand-binding plants in the shelterbelt along the Tarim Desert Highway. Chinese Science Bulletin, Beijing, v. 53, p. 109-111, 2008. 